\title{
City Branding of East Nusa Tenggara through the Video Narration Exotism of Sabu Island
}

\author{
Benedicta Yovi Claudia ${ }^{1}$, Rustono Farady Marta ${ }^{2}$, Ignatius Cahyanto ${ }^{3}$ \\ ${ }^{1,2}$ Master's Degree of Communication Science Department, Postgraduate Studies, \\ Universitas Bunda Mulia \\ Jl. Lodan Raya No. 2 Ancol Jakarta Utara 14430, Indonesia \\ ${ }^{3}$ University of Louisiana at Lafayette \\ 214 Hebrarb Boulevard, Lafayette, 70504, LA, United States \\ Email: benedictayoviclaudia@gmail.com*; rmarta@bundamulia.ac.id² ; ignatius.cahyanto@lousiana.edu ${ }^{3}$ \\ *Corresponding author
}

\begin{abstract}
East Nusa Tenggara (NTT), as one of the provinces with great tourism potential, applies city branding as a new tourism territory. This study aims to analyze (1) the meaning of the tourism promotion video Exotism of Sabu Island NTT in more depth and detail and (2) how the information messages conveyed in the tourism promotion video helped to advance the city branding of East Nusa Tenggara. This research employed a qualitative description method using Fisher's narrative paradigm, which consists of an analysis of the coherence and fidelity aspects of the narrative. The results showed that the video narrative Exotism of Sabu Island NTT has been successful in promoting East Nusa Tenggara as a new tourism territory through effective city branding. This video highlights Sabu Island, with its rich historical exoticism, landscape, and diversity of local cultural wisdom, as part of the East Nusa Tenggara province's tourism program. The main message conveyed in this video is the excellence of Sabu Island tourism, namely the exoticism of history, landscape, and diversity of local cultural wisdom. This video incorporates aspects of coherence and fidelity of the narrative that are appropriate and effective at city branding. The substance of this research provides new proposals regarding regional tourism city branding policies uploaded through promotional videos by applying the aspects of coherence and accuracy. Keywords: City Branding; Narrative Analysis; New Tourism Territory
\end{abstract}

Nusa Tenggara Timur sebagai salah satu provinsi dengan potensi wisata yang besar menerapkan city branding sebagai new tourism territory. Penelitian ini bertujuan untuk menganalisis (1) makna dari video promosi wisata Eksotisme Pulau Sabu NTT itu secara lebih mendalam dan mendetail dan (2) pesan informasi yang disampaikan dalam video promosi wisata tersebut membantu pembentukan city branding Nusa Tenggara Timur. Penelitian ini dilakukan dengan metode kualitatif deskripsi menggunakan paradigma naratif Fisher yang terdiri dari analisis aspek koherensi (coherence) dan ketepatan (fidelity) narasi. Hasil penelitian menunjukkan bahwa narasi video Eksotisme Pulau Sabu NTT telah mampu merepresentasikan city branding Nusa Tenggara Timur sebagai new tourism territory dengan baik. Hal ini ditunjukkan dari narasi bahwa Pulau Sabu dengan kekayaan eksotisme sejarah, bentang alam, dan keragaman kearifan budaya lokal merupakan bagian dari program wisata provinsi Nusa Tenggara Timur. Pesan utama yang disampaikan dalam video ini adalah keunggulan wisata Pulau Sabu yakni eksotisme sejarah, bentang alam, dan keragaman kearifan budaya lokal. Hal ini disertai dengan aspek koherensi (coherence) dan ketepatan (fidelity) narasi yang sesuai dan baik. Substansi penelitian ini memberikan usulan baru tentang kebijakan city branding pariwisata daerah diunggah melalui video promosi dengan menerapkan aspek koherensi dan ketepatan. Kata kunci: City Branding; Analisis Naratif; New Tourism Territory

\section{Introduction}

Since 2015, Indonesia's Ministry of Tourism has set ambitious targets in the tourism sector of 20 million foreign tourist arrivals in 2020, with $50 \%$ of the targeted visits directed at tourist destinations outside Bali (Fikri, 2019). The main target of the Ministry of Tourism of the Republic of Indonesia from 2015-2019 was to improve the ranking of Indonesian tourism, especially in terms of the number of tourists, both local and international. Gradually, KemenParRI plans to increase Indonesia's tourism ranking from 
seventy to thirty and has set a target to increase the number of tourists from nine million to twenty million (Kementerian Pariwisata, 2019).

The main objective of implementing this target is to develop tourism sector investment and improve the welfare of local communities and create jobs through the tourism sector. With the relatively high growth target of the tourism sector, the Ministry of Tourism invites all elements of the community, especially in this case, the regional governments who have authority over their respective regions (Anholt, 2011).

The tourism sector has been attractive and lucrative for several countries over the past few years. This is evidenced by the emergence of destination branding that prioritizes tourist destinations, city branding that prioritizes the excellence of the city, and the branding of other unique tourism sectors such as culinary, cultural, and natural beauty (Trisakti \& Alifahmi, 2018).

In order to support the optimization of the performance of the tourism sector in Indonesia, various efforts have been carried out including opening new leading tourist destinations in each region, increasing the promotion of the tourism sector, supporting the holding of cultural festivals in various regions, and supporting local governments to form city branding in the tourism sector. City branding is an effort by local governments to attract tourists and investors to the potential sectors in a region including the tourism sector. City branding is a forum for the formation of regional identity which has a positive impact on the region itself (Lichrou et al., 2017). The current potential for regional autonomy and globalization trends, the application of city branding is one of the most worthwhile efforts that can be made by the Regional Government in order to form a positive image of the city and utilize that image to promote the community (Lichrou et al., 2017).

For example, the development of city branding as a regional identity is carried out by the City of Bandung, namely by building the image of Bandung Champion. In this case, creativity and modernity are very dominant in Bandung's branding strategy. These efforts have proven to have a positive impact on the economic development for the people of Bandung. On the other hand, branding by prioritizing creativity and modernity is also considered by some to weaken the original Sudanese culture of the city of Bandung. Sundanese culture is not fully supported by the city branding strategy (Aldianto et al., 2019).

The use of city branding is also carried out by Yogyakarta by using student city branding to represent the image of Yogyakarta. The application of city branding is not only about developing a city image in a new program, but also considering the existing city attributes. The attributes that are considered to assess the brand image of Yogyakarta as a student city are many students from all over Indonesia, many well-known universities, many national or international quality universities, many libraries, many bookstores with complete collections, many bookstores. cheap, lots of sports facilities, lots of entertainment facilities, lots of housing/boarding facilities, affordable living costs (Haryono, 2009)

This illustrates that city branding has the potential to attract tourists and investors to various sectors in a region; however, city branding strategis should be carefully planned so as to not diminish or harm assets of a region or aspects of a region such as important cultural heritage. This demonstrates the need for analysis of the implementation of this city branding strategy as a form of evaluation to ensure that its application is on target and efficacious.

East Nusa Tenggara is one of the provinces with great tourism potential. To take advantage of this potential, the East Nusa Tenggara provincial government has implemented city branding as a strategy for this new tourism territory. The territory includes well-established areas, including Komodo Island, Kelimutu Lake, Alor Island, and emerging destinations such as 
Sabu Island. Sabu Island is considered to be a tourist destination that is a very high priority because it has a unique cultural richness and natural beauty such as the exotic rock group called Kallaba Madja in Sabu Raijua, which is called the abode of the gods. This is following the research of Utan, Wahyudi, and Asmaniati, F. (2017) that holding an event in East Nusa Tenggara is not only promoting tourism, but also raising East Nusa Tenggara city branding.

City branding effort by the East Nusa Tenggara provincial government has received support from various parties, including the tourism ministry, the local private sector, and various media outlets. Methods of city branding of a new tourism territory include the use of digital media such as YouTube. The YouTube video "Exotism of Sabu Island NTT" promotes the tourism sector of Sabu Island in NTT. "Exotism of Sabu Island NTT" was produced by Metrotvnews, which is the official national media channel.

This encourages researchers to conduct a narrative analysis of the video "Exotic Island Sabu Island NTT" as a form of City Branding of East Nusa Tenggara. The purpose of this narrative is to analyze media support for the tourism sector of Sabu Island and understand how the media helps to foster the city branding of East Nusa Tenggara as the new tourism territory. The results of the analysis, it is hoped that the audience better understand the meaning of the "Sabu Island Exotic Island" NTT tourism promotion video in greater depth and detail and see the extent to which the information message conveyed in the tourism promotion video helps establish NTT city branding as a new tourism territory. The results of this study are expected to provide an overview of the evaluation of the implementation of NTT city branding that has been carried out so far.

\section{City Branding}

City branding is the management of a destination image through strategic innovation and economic, commercial, cultural, and government regulation coordination (Moilanen
\& Rainisto, 2009). City branding is defined as a strategy for developing a place or city in which the city is viewed as a company that seeks to attract the attention of various stakeholders and customer groups (Kavaratzis, 2004). Branding can be defined as an image of a tourist area that is needed so that the appearance of the tourist area is fresher, more attractive, more memorable and in the end people come to visit the tourist area (Prayudi \& Herastuti, 2018).

City branding is also a tool borrowed from marketing practices by city planners to promote urban economic development. As a product, service, and organization, cities must develop a strong and unique image and reputation. Such image and reputation are needed in order to overcome city competition in fighting over economic resources at the local, regional, national, and global levels (Warnaby \& Medway, 2013).

Based on this understanding, it can be concluded that city branding is an effort to build cities through marketing strategies with the aim of aiding cities in forming a positive image and reputation. The purpose of engaging in city branding is to allow a city to firmly position itself so that it can attract investors, residents, tourists, and resources that will help to advance the progress of the city. City branding is accomplished through various forms of communication, both internally and externally.

City branding is seen as a strategic instrument that promotes the competitive advantage of cities. It is a broad practice for marketing the city's history, the quality of places, natural and cultural resources, social opportunities and attractiveness, lifestyle, nature opportunities, prestige, and strength in capital formation in dynamic markets (Zhang \& Zhao, 2009). However, increasingly fierce competition between cities, which involves universal manipulation of the visual presentation of resources, capital, and social environment, presents a challenge to efforts to form the image of the city (Kavaratzis \& 
Hatch, 2013). Researchers in various scientific disciplines have emphasized the storytelling approach with media narratives as effective and influential techniques to rejuvenate brands and to drive market changes (Aaker \& Smith, 2011).

Several studies have established that City branding is now widely used to promote the potential of an area, especially in the field of tourism. One such study was carried out by the City of Bandung, namely by building the image of Bandung Champion. In this case, creativity and modernity are very dominant in Bandung's branding strategy. This effort is proven to have had a positive impact on economic development for the people of Bandung. On the other hand, branding by prioritizing creativity and modernity is also considered to be a contributing factor to the decline of the original culture of the city of Bandung. Sundanese culture as the original culture of the city of Bandung is not fully supported by this city branding strategy (Aldianto et al., 2019).

The results of this study indicate that the application of city branding can bring positive and negative impacts on its implementation. For this reason, researchers emphasize the urgency of analyzing the implementation of city branding from the point of view of communication to better understand the meanings and messages conveyed in the media promotion of city branding. This analysis can help in determining if the strategies employed are appropriate and if the strategies positively and appropriately represent the image of the area.

City branding is an internationally recognized research domain that involves various disciplines and widely fragmented domains of analysis. The analysis of city branding itself is quite broad, covering three perspectives identified from various disciplines for the purpose of identifying the production process, public consumption, and evaluating the application of city branding itself (Mihalis Kavaratzis \& Hatch, 2013).

\section{Narrative Analysis}

Eriyanto (2013) explained that narrative analysis is an analysis of narration, both fiction and non-fiction. The use of narrative analysis involves placing the text as a story (narration) in accordance with the characteristics of the narrative. The text is seen as a series of stories, events, logic, and the order of events to the selected and discarded.

Narrative is the overall story and storytelling style (plot). The narrative technique as an analytical method is useful for seeing the whole media as a form of mass communication with a distinctive character, which television programs and audio-visual documentaries do not have (Kristiyono \& Sirikit, 2019).

The narrative analysis uses the narrative paradigm theory that human beings are narrators and that values, emotions, and aesthetic considerations underlie our beliefs and behavior (Fisher, 1984). The main concept of the narrative paradigm theory consists of a narrative and narrative rationality. Narrative rationality is a standard of judgment in which a story will either be believed or rejected. Narrative rationality operates on two different aspects, namely coherence and fidelity. Coherence refers to internal narrative consistency. The assessment of coherence in the story must pay attention to narrative questions that are inconsistency. Narratives are coherent when all parts of the story are present, including important details and opposing elements. Coherence consists of two aspects: structural coherence (coherence that refers to the flow of the story) and material coherence (coherence thatrefers to the congruence between one story and another story that is opposite). Fidelity is the principle of narrative rationality which assesses the credibility of a story.

The narration itself is useful in the representation of a destination object because of its relationship with language and the way people create social reality. Narration is the main mode of human knowledge and human communication (Lichrou et al., 2010). Narration is an important medium in the delivery of messages, one of which is in the promotion of city branding in an area. 
Previous research related to the narrative of city branding has also been conducted. In these studies, three aspects of narration in the promotion of city branding were analyzed. The first reflects the informal approach that characterizes promotion, marketing, and branding. The second facet of research centered around critical reflection on the theory and practice of existing city branding. The third angle of research was on the role of a narrative in presenting a message that is concise but contains broader meta-narratives (Zenker, 2011).

This is the aim of this research to analyze (1) the meaning of the tourism promotion video "Exotic Island Sabu NTT" in more depth and detail and (2) the information messages conveyed in the tourism promotion video which helped to form the East Nusa Tenggara city branding.

\section{Research Methods}

This research is descriptive qualitative research using interpretive paradigms. The focus of this research is to analyze (1) the meaning of the tourism promotion video "Exotism of Sabu Island NTT" in more depth and detail and (2) the information messages conveyed in the tourism promotion video, which helped to form the East Nusa Tenggara city branding. The object of this research is the video narrative "Exotism of Sabu Island NTT" which is a tourism promotion media that represents one of city branding tools of East Nusa Tenggara.

The data collection technique was carried out by studying the video documentation of "Exotism of Sabu Island NTT" available on YouTube and literature from relevant literature. The qualitative data analysis was carried out by a narrative analysis technique on the video "Exotism of Sabu Island NTT." The choice of narrative analysis is based on the assumption that this narrative analysis is suitable for analyzing the meaning of messages in a narrative used for city branding because it is able to reflect the informal and improvised approaches that characterize promo- tion, marketing, and branding. The results of the analysis of the meaning of the message of the city branding narrative is then used to evaluate the application of the regional city branding that is analyzed to see the suitability of its implementation.

\section{Results of Research and Discussion}

The transformation of the Indonesian government's mechanism from centralization to decentralization has brought a new perspective on government leadership and management, especially in the regions. Local governments such as cities, districts, or provinces have almost full authority to administer their own government. The government makes various efforts to achieve positive regional development, one of which is city branding. City branding is an effort to build a city through a marketing strategy with the aim of forming a positive image and reputation as the identity of a region. City branding not only shows the image of the region but also showcases the identity, background, and character of the area.

East Nusa Tenggara is one area that utilizes city branding as a regional development strategy. The NTT city branding is carried out with the new tourism territory tagline, by offering superior destinations such as Komodo Island, Kelimutu Lake, Alor Island, to new destinations such as Sabu Island. The city branding effort by the East Nusa Tenggara provincial government has the support of various parties both from the tourism ministry, the local private sector, to various media. The video "Exotism of Sabu Island NTT" is part of the media package that promotes the tourism sector of Sabu Island in NTT. Video Sabu Island is introduced as an emerging tourist destination deemed as a very high priority because it has a unique cultural richness and natural beauty, such as an exotic rock group called Kallaba Madja in Sabu Raijua which is called the abode of the gods. 


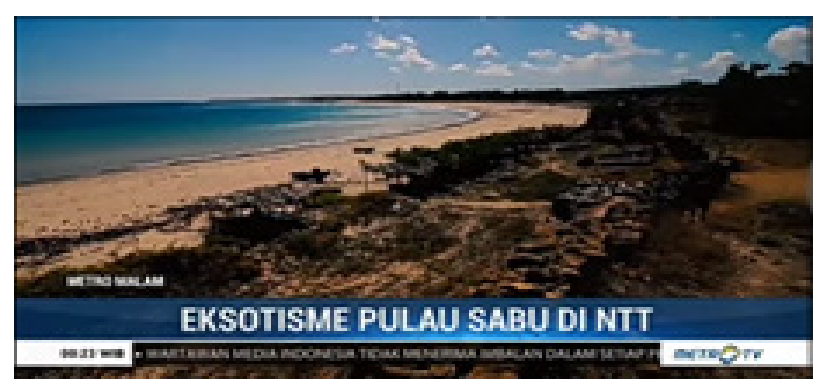

Figure 1. Display of Opening Coverage with Beach Background and Exotic Headline of Sabu Island in NTT

Source: Metronews (2019)

Promotional videos act as advertisements in the mass media and can be used to create a brand image and symbolic appeal for a company or brand. This is very important, especially for products that are difficult to distinguish in terms of quality and function from competing products and advertisers must be able to take advantage of advertisements in the mass media to position their products in the eyes of consumers (Tianotak \& Asy'ari, 2019).

In order to analyze and describe the narrative meaning of the video "Exotism of Sabu Island NTT" as a form of representation of the East Nusa Tenggara city branding as a new tourism territory, a narrative analysis was carried out. Based on the results of the analysis of this study, the following findings were obtained.

\section{Prologue}

The prologue is in the form of news broadcasts with an opening narrative that introduces Sabu Island as a tourist destination that is worth a visit while visiting East Nusa Tenggara. The following is a video prolog transcript that shows these findings. (Setting: Prolog siaran berita MetroTV) Pemirsa ketika kita berkunjung ke Provinsi Nusa Tenggara Timur tidak ada habisnya. Ketika kita menikmati eksotisme alam NTT yang memiliki khasanah budaya dan juga sejarah salah satunya di Pulau Sabu di selatan Nusa Tenggara Timur yang menyimpan eksotisme pantai yang begitu menawan. Berikut informasinya untuk anda.
The prologue display of the video shows that this tourism promotion video is a news broadcast that was resubmitted as a form of support for the introduction of Sabu Island as a leading tourist destination in NTT. The meaning of this initial narrative is that Sabu Island in the south of East Nusa Tenggara is part of NTT's natural exoticism, which has rich cultural and historical treasures and must be visited when visiting NTT.

\section{Beginning}

After the prologue, news broadcasts were shown with material containing the appearance of the beach and aerial imagery of Sabu Island. The first part of this broadcast shows that the video has begun to be directed to the coverage of material about Sabu Island. The following is a transcript of the part of the video that shows these findings.

(Setting: Tampilan pantai dengan judul liputan di bagian bawah bertuliskan Eksotisme Pulau Sabu di NTT) Inilah Pulau Sabu dengan eksotisme sejarah, bentang alam, dan keragaman kearifan lokal yang masih dipelihara hingga kini.

In this section, the coverage material about Sabu Island is shown in the form of a video which shows the beautiful appearance of Sabu Island beach. As for the display of the beauty of the coast of Sabu Island, there is also a video narrative that emphasizes the Sabu Island with the exoticism of history, landscape, and diversity of local wisdom that is still maintained today. The narrative of historical exoticism, landscape, and diversity of local wisdom is the main idea to be conveyed from this video because it confirms the previous narration in the prologue stating that Sabu Island in the south of East Nusa Tenggara is part of NTT's exoticism which has cultural and historical treasures which is rich and must be visited when visiting NTT.

The narration continues with an introduction about the location of Sabu Island and its geographical description, which reads as follows. 


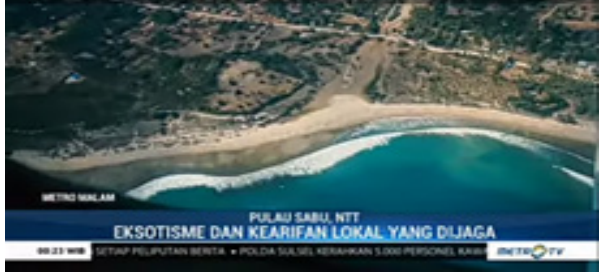

Figure 2 Satelite Image of NTT Sabu Island Source: Metronews (2019)

(Setting:Tampilan citra udara pulau sabu) Pulau yang terletak di selatan Nusa Tenggara Timur ini adalah sebuah pulau dengan satu kabupaten yang terpisah dari pulau besar di NTT lainnya seperti pulau flores sumba dan timor. Also shown is the display of aerial imagery of Sabu Island as supporting information on the location of Sabu Island and the geographical description of Sabu Island.

\section{Main part}

The video display and narration are focused on the main message of this video coverage in the form of the exoticism of history, landscape, and diversity of local wisdom from Sabu Island. The first message is a message about the beauty of nature. This is shown in the description of the beauty of the beach, which is shown through a video display that is accompanied by a narrative about the topography of the island of Sabu, which is the main point of this tourist destination. The following is a transcript of the part of the video that shows these findings. (Setting: Tampilan detail pantai) Pulau dengan topografi batuan kapur dan kering ini sungguh memikat hati. Hamparan pasir putih batu karang menjadi sebuah keunikan yang sangat memanjakan mata.

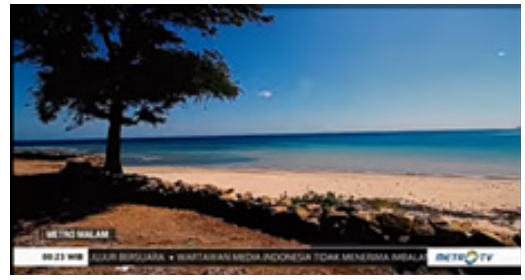

Figure 3. Beach Detail Display Source: Metronews (2019)

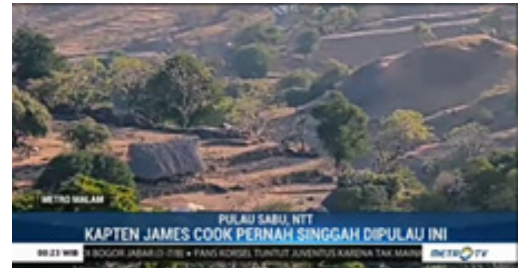

Figure 4. Panorama View of Sabu Island with Captain James Cook Headline Ever Stopped on Sabu Island

Source: Metronews (2019)

The next message covers the historical exoticism of Sabu Island. This description of historical exoticism is depicted in a narrative that explains how Sabu Island has a history as an island once visited by Captain James Cook, who discovered the Australian continent. This narration explains that the local King at that time - King Madokolo Mijara - also helped James Cook prepare their supplies to continue the journey to Batavia. The following is a transcript of the part of the video that shows these findings:

(Setting: Headline judul Captain James Cook Pernah Singgah di Pulau Ini) Tahukah anda ternyata Captain James Cook sebelum menemu-kan benua australia dengan kapal Endefur-nya pernah singgah di pulau ini pada 17 sampai 21 september 1770. Konon di pantai ini Kaptain James Cook turun pertama kali di pulau sabu. Di pantai ini Kaptain Cook pernah meminta bantuan Raja Madokolo Mijara untuk mengisi perbekalan mereka sebelum melanjutkan perjalanan menuju batavia. The next message is about the other side of the natural beauty of Sabu Island. This section emphasizes that the natural beauty of Sabu Island is unlimited and has a unique variety so that the delivery of the message is

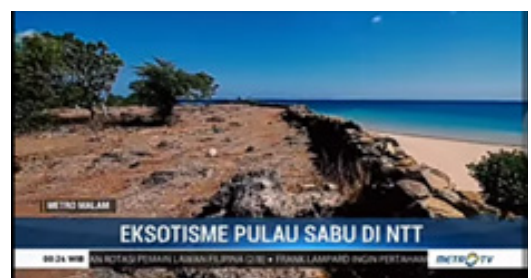

Figure 5 Detailed view of the beach with the headline Exotism of Sabu Island NTT Source: Metronews (2019) 


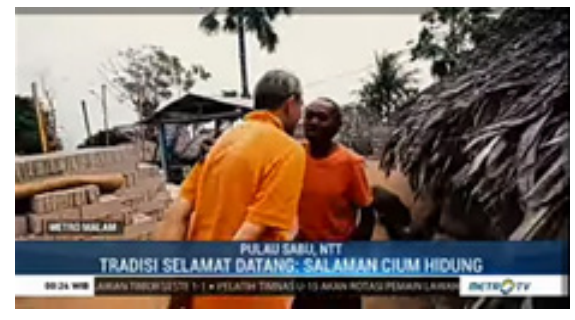

Figure 6 Video Display of Sabu Island with Welcome Tradition Headline: Kiss the Nose Shake Source: Metronews (2019)

repeated. The following is a transcript of the part of the video that shows these findings.

(Setting: Tampilan detail pantai dengan headline Eksotisme Pulau Sabu di NTT) Disambut pantai pasir putih yang luas dan indah dengan batu karang yang curam terdapat pula kerang atau cangkang siput besar yang biasa digunakan warga sebagai tempat penguapan air laut agar bisa menghasilkan garam.

The next message is about the wisdom of Sabu Island culture. This message was conveyed through a video display accompanied by a narrative about the tradition of welcoming guests using the greetings typical of Sabu Island, namely the tradition of kissing the nose. This part of the video shows the diversity and cultural wisdom of Sabu Island, which also shows the hospitality of the local people. The following is a transcript of the part of the video that shows these findings.

(Setting: Headline Tradisi Selamat

Datang: Salaman Cium Hidung) Eksotisme pantai kian lengkap dengan keramahan warga sekitar. Untuk menyambut tamu biasanya warga menyalami kita dengan salam khas sabu yakni cium hidung Finally, a message was returned related to diversity and local wisdom and cultural uniqueness on Sabu Island. This is shown by the video display and narration about the habits of men on Sabu Island climbing palm trees to make sugar. This seems to indicate the presence of typical palm sugar processed Sabu and introduce the main work of the local population as part of the cultural treasures preserved by the inhabitants of the island of Sabu. The following is a transcript of the part of the video that shows these findings.

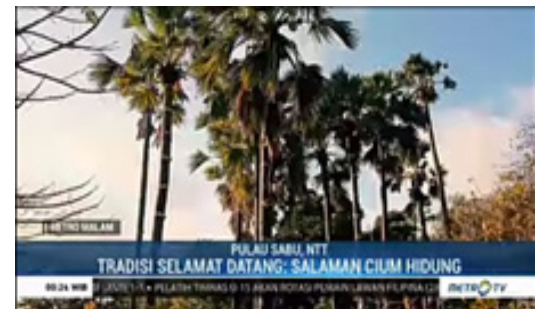

Figure 7 Video Display of Customary Community Coverage Processing of Lontar

Source: Metronews (2019)

(Setting: Liputan Kebiasaan Masyarakat MengolahLontar)Dipulauinibiasanyakaum pria memanjat pohon lontar untuk dijadikan gula sebagai penghasilan utama keluarga.

\section{Closing Section}

The closing part of this video is delivered in the form of a closing statement from the news coverage. This indicates that although this coverage promotes Sabu Island as a new tourist destination in NTT, it is still presented in the form of news coverage.

The results of the analysis of the meaning of the narrative in the video "Exotism of Sabu Island NTT" it can be obtained several meanings of the message contained therein. In accordance with the narrative paradigm used in the narrative analysis of this research, the analysis is carried out by looking at the coherence and fidelity aspects of the analyzed video.

In terms of coherence, the video narrative of "Exotism of Sabu Island NTT" has an idea that is united with one another. The main message is the island of Sabu with the exoticism of history, landscape, and diversity of local wisdom that is still maintained today. In this case, the narrative of the exoticism of history, landscape, and diversity of local cultural wisdom is the main message that is trying to be conveyed by video makers. This is shown by the introduction of the narrative idea from the prologue section and the beginning of the coverage, which is then clarified in detail in the content section. 
Good use of coherence results the narrative video "Exotism of Sabu Island NTT" is considered successful in representing objects that are well promoted. The results of a coherent narrative can be assumed that the narrative can be used to attract tourists and invite regional investment.

This is consistent with the opinion of Lichrou, et al (2017) which states that City branding is a social construction that is intended to strengthen the image of a place to attract the attention of local audiences and provide 'unique' offers for potential investors and tourists. Thus City branding can be said as a form of strategy in the top-down process by tourism marketing organizations. However, this approach has been criticized because there are often gaps between the image in question and the reality experienced (Lichrou et al., 2017)

Result of discussion regarding the message of the representation of the city branding of East Nusa Tenggara as the new tourism territory was also conveyed well in this video. This is shown by the initial narration of the video that reads, "Sabu Island in the south of East Nusa Tenggara is part of NTT's natural exoticism which has rich cultural and historical treasures and must be visited while visiting NTT." This message shows that Sabu Island, with its rich historical exoticism, landscape, and diversity of local cultural wisdom is part of the East Nusa Tenggara province's tourism program. Besides that, there is no contradictory part of the coverage that means that the overall narration of the tourism promotion video titled "Exotic of Sabu Island NTT" is coherent.

Furthermore, in terms of accuracy (fidelity), the video narrative "Exotism of Sabu Island NTT" is also quite good. This is shown from the delivery of the contents of the coverage that is accompanied directly with a video display of the intended message. This shows evidence that Sabu Island does have a rich exoticism of history, landscape, and diversity of real and real local cultural wisdom in accordance with the coverage delivered. In addition, the style of delivering narrative news is also relevant to the actual coverage material and is delivered consistently. Thus the delivery of the narrative video "Exotism of Sabu Island NTT" can be said to have aspects of the accuracy of the delivery of a good narrative coverage.

Some cities have had great success in organizing city branding. There are many benefits in doing city branding, not only for economic development but also for cultural and social impacts for city communities. But it cannot be denied that there are also a number of cities that face failure in conducting city branding (Yuli, 2011). This is why in the implementation of city branding, aspects of narrative fidelity must be considered. If the narrative shown in the promotion does not match the reality on the ground, then the formation of city branding will also not go well.

In this case, the researchers compared the results of the Semarang city branding, which was previously studied by Yuniningsih \& Suwitri (2017). The city branding city of Semarang using the tagline The Beauty of Asia was considered a failure. The reason for the failure was partly because the tagline was considered irrelevant to the condition of the city of Semarang. The second reason is to try to use the word "Asia" which has an excessive perception and is too high. This causes people to think that Semarang city branding is not realistic (Yuniningsih \& Suwitri, 2017).

On the other hand, when the fidelity aspect of the narrative matches the reality on the ground, the implementation of city branding can also be successful. In another study the Banyuwangi city branding program was shown as an example of a successful city branding program. Banyuwangi city with the tagline The Sunrise of Java is considered able to bring the image of the city of Banyuwangi as an attraction for tourists to come to Banyuwangi (Jannah, 2014).

In order to give a brand for itself, a region needs an integrated communication policy or framework that coordinates the ways countries portray or describe themselves (Irwansyah, 2013). In this case, the narrative video "Exotism 
of Sabu Island NTT" has the advantage that the visual presentation of the beauty of the panorama of Sabu Island is shown naturally so that the level of accuracy of the narrative material is very relevant to reality on the ground. In addition, the presentation of cultural elements also becomes more points for the narration of this video because the culture is an element of local wisdom that is identical and different in each region. This shows evidence that Sabu Island does have a rich exoticism of history, landscape, and diversity of real and real local cultural wisdom in accordance with the coverage delivered. In addition, the style of delivering narrative news is also relevant to the actual coverage material and is delivered consistently. Thus the delivery of the narrative video "Exotism of Sabu Island NTT" can be said to have aspects of the accuracy of the delivery of a good narrative coverage.

Result of narrative analysis, it can be seen that the introduction of city branding in East Nusa Tenggara through the video narrative "Exoticism of Sabu Island" is an example of a good and effective introduction to regional city branding. In the future, the introduction of regional tourism city branding through promotional videos uploaded to social media needs to be done more intensively with previously prepared narratives. This needs to be done so that the benefits of the promotional video narrative can really help the introduction of city branding in the target area. Videos that promote regional city branding will later become one of the media to introduce regional excellence, especially in the tourism sector, which is expected to attract visitors.

\section{Conclusion}

Based on the results of the analysis and discussion of this study, it is known that the video narrative "Exotism of Sabu Island NTT" has been able to represent the city branding of East Nusa Tenggara as a new tourism territory. This is shown by the narrative that Sabu Island, with its rich historical exoticism, landscape, and diversity of local cultural wisdom, is part of the
East Nusa Tenggara province's tourism program. The main message delivered in this video is the excellence of Sabu Island tourism, namely the exoticism of history, landscape, and diversity of local cultural wisdom. This is accompanied by aspects of coherence and the accuracy (fidelity) of an appropriate and good narrative.

The implementation of city branding so far has been successful in several cities in the world and has a positive impact on society's magic. However, it cannot be denied that if it is not executed properly, the application of city branding will not develop and negatively affect the city concerned. The application of city branding through the video narrative "Exotism of Sabu Island NTT" has been able to represent East Nusa Tenggara as a new tourism territory so that its application can be an ideal example for other cities that want to develop their regions with the concept of city branding. In order to achieve the successful implementation of city branding, the researcher suggests paying attention to the use of coherence and fidelity aspects of the narrative that are appropriate and good.

Based on these findings, it can be concluded that the introduction of city branding in East Nusa Tenggara through the video narrative "Exoticism of Sabu Island" is an example of a good and effective introduction to regional city branding. This is due to the use of appropriate and good narrative coherence and fidelity aspects. This can be an example for other regions in introducing city branding in their respective regions in order to support regional development.

The substance of this research is a suggestion of regional tourism city branding through promotional videos uploaded to social media needs to be done more intensively with previously prepared narratives. This needs to be done so that the benefits of the promotional video narrative can really help the introduction of city branding in the target area. Videos that promote regional city branding will later become one of the media to introduce regional excellence, especially in the tourism sector, which is expected to attract visitors. 


\section{References}

Aaker, J., \& Smith, A. (2011). The Dragonfly Effect. Standford Social Innovation Review.

Aldianto, L., Budi,A.A., Anggadwita, G., Novani, S., \& Wirawan, C. (2019). City Branding vs. Cultural Branding: Towards a Theoretical for Developing Bandung Identity. Kinerja. https://doi.org/10.24002/kinerja.v22i2.2125

Anholt, S. (2011). Competitive Identity. In Destination Brands. https://doi. org/10.1016/b978-0-08-096930-5.10002-3

Eriyanto. (2013). Analisis Naratif: Dasar-dasar danPenerapannyadalam Analisis Teks Berita Media. Kencana Prenada Media Group.

Fikri. C. (2019, Maret 20). Menpar Targetkan Destinasi Indonesia Bestandar Internasional. Beritasatu.com. https://www.beritasatu. com/nasional/544073-menpar-targetkandestinasi-indonesia-bestandar-internasional

Fisher, W. (1984). Narration as a human communication paradigm. Communication Monographs, 51(1), 1-22. https://doi. org/ $10.1080 / 03637758409390180$

Haryono, S. (2009). Analisis Brand Image Yogyakarta sebagai Kota Pelajar. Jurnal Ilmu Komunikasi, 7(3), 301-309. Retrieved from http://jurnal.upnyk.ac.id/ index.php/komunikasi/article/view/28

Irwansyah. (2013). Menginisiasi Nation Branding Indonesia Menuju Daya Saing Bangsa. Jurnal Ilmu Komunikasi, 11(1), 8091. Retrieved from http://jurnal.upnyk.ac.id/ index.php/komunikasi/article/view/305

Jannah, B. (2014). Pengaruh City Branding dan City Image Terhadap Keputusan Berkunjung Wisatawan ke Banyuwangi. Jurnal Administrasi Administrasi Bisnis, 17(1), 1-7. Retrieved from http:// administrasibisnis.studentjournal. ub.ac.id/index.php/jab/article/view/679

Kavaratzis, M. (2004). From City Marketing to City Branding: Towards a Theoretical Framework for Developing City Brands. Place Brand Public, 1, 58-73. https:// doi.org/10.1057/palgrave.pb.5990005
Kavaratzis, M., \& Hatch, M. J. (2013). The Dynamics of Place Brands: an IdentityBased Approach to Place Branding Theory. Marketing Theory, 13(1), 69-86. https:// doi.org/10.1177/1470593112467268 Kementerian Pariwisata. (2019, Juli 2). Siaran Pers : Industri Perjalanan Wisata Indonesia Siap Dukung Pemerintah Datangkan 20 Juta Wisman. Kemenparekraf.go.id. Retrieved from https://www.kemenparekraf. go.id/index.php/post/siaran-pers-industriperjalanan-wisata-indonesia-siap-dukungpemerintah-datangkan-20-juta-wisman Pradipta, G. (2020, Agustus 16). Cerita di Balik Keputusan Jokowi Kenakan Baju Adat Sabu Raijua. Kompas.com. Diambil dari https://nasional.kompas. $\mathrm{com} / \mathrm{read} / 2020 / 08 / 16 / 08370761 /$ cerita-di-balik-keputusan-jokowikenakan-baju-adat-sabu-raijua Lichrou, M., O’Malley, L., \& Patterson, M. (2010). Narratives of a Tourism Destination: Local Particularities and Their Implications for Place Marketing and Branding. Place Branding and Public Diplomacy, 6, 134144. https://doi.org/10.1057/pb.2010.10 Lichrou, M., O’Malley, L., Patterson, M., \& O'Leary, K. (2017). Place Branding and Place Narratives. In A. Campelo (Ed.), Handbook on Place Branding and Marketing (pp. 160-177). The Rockefeller Foundation. metronews. (2019). Eksotisme Pulau Sabu. Retrieved at Mei 23, 2020, from https:// www.youtube.com/watch? $\mathrm{v}=\mathrm{PdDiJrPCzZ4}$ Moilanen, T., \& Rainisto, S. (2009). How to Brand Nations, Cities and Destinations. In How to Brand Nations, Cities and Destinations. https://doi.org/10.1057/9780230584594 Prayudi, \& Herastuti, H. (2018). Branding Desa Wisata Berbasis Ecotourism. Jurnal Ilmu Komunikasi, 16(3), 227-237. Rtrieved from http://jurnal.upnyk.ac.id/ index.php/komunikasi/article/view/3204 
Tianotak, J., \& Asy'ari, N. A. S. (2019). Makna Tagline 'Menjadi yang Terbaik' Iklan Telkomsel Versi Pilot Papua Riko Kabak. Bricolage: Jurnal Magister Ilmu Komunikasi, 5(1), 49-72. http://dx.doi. org/10.30813/bricolage.v5i01.1742

Trisakti, F. A., \& Alifahmi, H. (2018). Destination Brand Storytelling: Analisis Naratif Video The Journey to A Wonderful World Kementerian Pariwisata. Jurnal Komunikasi Indonesia, 7(1), 73-86. https://doi.org/10.7454/jki.v7i1.9692 Utan, F. M. E., Wahyudi, A. S., Asmaniati, F. (2017). The Impacts of Tour de Flores Event for Tourism Development in West Manggarai, Nusa Tenggara Timur. Tourism Research Journal, 1(1), 144152. https://doi.org/10.30647/trj.v1i1.14 Warnaby, G., \& Medway, D. (2013). What about the "place" in place marketing? Marketing Theory. https:// doi.org/10.1177/1470593113492992
Yananda, R. M. (2014). Branding Tempat: Membangun Kota, Kabupaten, dan Provinsi Berbasis Identitas. Makna Informasi. Yuli, A. (2011). City Branding Sebagai Strategi Pengembangan Pariwisata ditinjau dariAspek Hukum Merek (Studi Kasus City Branding Daerah Istimewa Yogyakarta Sebagai Daerah Tujuan Wisata Unggulan di Indonesia). QISTIE: Jurnal Ilmu Hukum, 5(1), 50-68. https://doi.org/10.1057/9780230294790

Yuniningsih, T., \& Suwitri, S. (2017). Partisipasi Masyarakat Dalam Pengembangan City Branding Kota Semarang Jawa Tengah Indonesia. Prosiding SEMNASFI, 1(1), 165174. https://doi.org/10.21070/semnasfi.vli1

Zenker, S. (2011). From City Marketing to City Branding: an Interdisciplinary Analysis with Reference to Amsterdam, Budapest and Athens. Journal of Place Management and Development. https:// doi.org/10.1108/17538331111117151

Zhang, L., \& Zhao, S. X. (2009). City branding and the Olympic effect: A case study of Beijing. Cities, 26(5), 245-254. https:// doi.org/10.1016/j.cities.2009.05.002 